\title{
SOBRE ERRÂNCIAS, IMPRECISÕES E AMBIVALÊNCIAS: NOTAS SOBRE AS TRAJETÓRIAS DE JOVENS CARIOCAS E SUA RELACÃAO COM O MUNDO DO CRIME*
}

\author{
João Trajano Sento-Sé \\ Maria Claudia Coelho \\ Universidade do Estado do Rio de Janeiro - Brasil
}

Resumo: A literatura sobre juventude e violência é muitas vezes orientada pela busca de correlações entre, de um lado, os vínculos familiares, a inserção escolar e as perspectivas de futuro e, de outro, o envolvimento dos jovens com a violência, como vítimas ou agressores. O objetivo deste texto é problematizar essas correlações por meio do estudo comparativo de relatos de jovens em três diferentes situações concernentes às formas de institucionalização: a) em cumprimento de medidas socioeducativas; $b$ ) inseridos no sistema escolar público; e c) afastados de qualquer tipo de vínculo institucional. A metodologia empregada foi a entrevista em profundidade, com um roteiro que versou sobre as relações familiares, a trajetória escolar, projetos para o futuro e experiências com a violência e o crime. A análise apontou pistas para o questionamento do valor heurístico daquela entronização da escola e dos vínculos familiares como marcos de referência para o estudo das experiências jovens.

Palavras-chave: criminalidade, institucionalização, juventude, violência.

Abstract: Literature on the issue of youth and violence is usually guided by the search for correlations between family bonds, school enrollment and future expectations and young people's involvement with violence, as victims or perpetrators. This paper intends to call into question these correlations through a comparative study of narratives produced by young men and women in three different situations concerning forms of institutionalization: a) those subjected to socio-educative measures; $b$ ) those enrolled in the public education system; and c) those deprived of any kind of institutional bonds. Methodology consists of in-depth interviews based on four major topics:

* Este artigo apresenta resultados do projeto "Juventude e Violência no Rio de Janeiro", apoiado pela Finep (2007- 2011 - Coordenação Geral: Ignacio Cano). 
family relations, educational trajectory, projects for the future and experiences with violence and crime. Analysis raised relevant cues for questioning the heuristic value of attributing to school and family the role of central references for the understanding of youth experiences.

Keywords: criminality, institutionalization, violence, youth.

\section{Introdução}

Pesquisas realizadas em diferentes partes do mundo atestam reiteradamente uma tendência maior de jovens a se envolverem em práticas criminais implicando violência, tanto como perpetradores, quanto na condição de vítimas. Tal tendência se daria em função dos hábitos e códigos próprios a essa faixa etária, conforme alegam os proponentes da teoria do estilo de vida (Zimring, 1998). A mesma concentração ocorre com homens que, comparativamente a mulheres, participam mais do mesmo universo. Possivelmente, adicionado ao modo de vida próprio dos jovens, os garotos estariam menos sujeitos ao controle e aos cerceamentos, o que os tornaria mais suscetíveis, atestam pesquisadores ancorados na teoria do controle (Wilson, 1980). A moradia em espaços degradados, o pertencimento a grupos estigmatizados, o exemplo transmitido por pais ou parentes próximos, eles mesmos inseridos em uma trajetória de criminalidade contumaz, são chaves analíticas privilegiadas para correntes como a teoria situacional (Clarke, 1997), a teoria das subculturas (Becker, 1963), a labeling theory (Katz, 1988) ou a teoria do aprendizado. É claro que podemos conceder nossa fé ao universalismo econômico das teorias da escolha racional e supor simplesmente que, sendo todos motivados fundamentalmente pelas mesmas paixões, o envolvimento criminal não passa do resultado de um cálculo utilitário, tal como explicado pela teoria das oportunidades.

São tão volumosas as pesquisas que associam a fragmentação familiar, o fracasso escolar e as baixas perspectivas de futuro a comportamentos criminais reiterados, que tais variáveis se tornaram uma espécie de paradigma para a análise do crime como fenômeno social. Esses três elementos têm se revelado bastante consistentes, mas não exatamente conclusivos, na explicação de comportamentos criminais.

Transformar paradigmas explicativos em dados naturalizados de certas dinâmicas sociais é um risco contra o qual se deve adotar o salutar exercício

Horizontes Antropológicos, Porto Alegre, ano 20, n. 42, p. 327-357, jul./dez. 2014 
da dúvida. É esse o nosso intuito presente. Embora consistente, a assunção das três variáveis mencionadas como vetores concorrentes para a configuração de trajetórias criminosas é empiricamente sujeita a problematizações, sobretudo os dois primeiros. Problematizar não implica, naturalmente, refutar. Antes, trata-se de alargar o conhecimento sobre tais categorias e suas possíveis significações. A questão que nos intriga pode ser posta nos seguintes termos: como evitar a reificação de um modelo de família, bem como de uma dada trajetória que, uma vez não cumprida, concorreria para danos suficientemente fortes para definir trajetórias "anômicas"?

O percurso escolhido foi ouvir relatos de jovens em três diferentes situações pertinentes ao conjunto de problemas implicados nessas perguntas. ${ }^{1}$ Jovens de ambos os sexos cumprindo medidas socioeducativas; jovens inseridos no sistema escolar público do Rio de Janeiro; e, finalmente, jovens que interromperam precocemente sua trajetória escolar e que se encontravam, no momento da entrevista, afastados de qualquer tipo de vínculo institucional.

A análise foi dividida em dois grandes blocos. No primeiro, abordamos a trajetória dos jovens que não contavam com qualquer vínculo institucional no momento em que os entrevistamos. Colhemos relatos de suas respectivas trajetórias, suas perspectivas de curto e médio prazo e suas experiências com familiares, amigos, comunidades de origem e ambientes escolares. Posteriormente, fizemos o mesmo exercício com os depoimentos dos jovens vinculados à rede escolar e daqueles que cumpriam medidas socioeducativas. ${ }^{2}$

A primeira seção deste artigo traz a análise dos depoimentos dos jovens não institucionalizados. Na segunda seção, apresentamos a análise dos depoimentos dos jovens em cumprimento de medidas socioeducativas e dos jovens escolarizados. Entrelaçamos a essas duas seções dois "arremates". No primeiro, discutimos a problematização que a análise nos exigiu da noção mesma de "trajetória"; no segundo, esboçamos, à guisa de conclusão, uma reflexão sobre o tributo que a própria concepção desta pesquisa pagou a matrizes conservadoras e normativas que perpassam as análises sobre as relações entre juventude e violência.

\footnotetext{
1 O projeto original incluiu um quarto grupo de jovens participantes do Programa Nacional de Inclusão de Jovens (ProJovem). Por razões de espaço, suprimimos aqui a análise relativa a esse grupo.

2 Foram realizadas 38 entrevistas no Departamento Geral de Ações Socioeducativas (Degase), com rapazes e moças, das quais utilizamos aqui 28. As entrevistas realizadas com jovens escolarizados são em número de 17.
}

Horizontes Antropológicos, Porto Alegre, ano 20, n. 42, p. 327-357, jul./dez. 2014 


\section{Vínculos, inserções, pertencimentos}

\section{Os jovens e suas famílias}

A leitura do conjunto das entrevistas impressiona pela dificuldade de identificar qualquer padrão de estrutura familiar predominante. A impressão geral é de indivíduos "desgarrados", sem vínculos estáveis, com trajetórias marcadas por extrema mobilidade, tanto no sentido da composição do grupo familiar com o qual mantêm relações de coabitação quanto no sentido das áreas da cidade em que habitam.

Os modelos construídos pelos estudiosos - “família nuclear”, “famílias monoparentais", "família extensa", etc. - parecem insuficientes para dar conta da experiência familiar desses jovens, não somente devido à diversidade na composição dos grupos familiares, mas também em sua variabilidade, em períodos às vezes curtos de tempo. Falar em "famílias desestruturadas" parece intelectualmente tentador no sentido de abrigar em um único rótulo experiências cujas marcas são justamente a instabilidade e a variabilidade; o juízo valorativo aí evidente recomenda, contudo, a busca de uma alternativa.

Nesta seção, a proposta é expor três aspectos nos quais estas características surgem: a) a composição familiar; b) a mobilidade espacial; e c) a dimensão afetiva.

Nos vínculos familiares desses jovens não parece haver uma conexão necessária entre parentalidade e coabitação. As combinações são as mais diversas, havendo uma entrevistada que foi deixada pela mãe aos cuidados da outra esposa do pai, que tinha duas famílias ao mesmo tempo; recorrente presença das avós habitando a mesma moradia; e intenso recurso aos tios e tias, tanto como responsáveis pelos entrevistados quanto, em um movimento lógico de reprodução intergeracional desse mesmo padrão familiar, de responsabilização dos entrevistados pelas crianças filhas de seus irmãos e irmãs.

Esse aspecto de intensa variabilidade na composição familiar é também uma característica do padrão espacial de habitação desses jovens. Os entrevistados relatam uma intensa mobilidade, com alguns já tendo morado em áreas não só muito afastadas entre si como de características muito diferentes (bairros de regiões abastadas da cidade, comunidades carentes, subúrbios, etc.), com essa mobilidade com frequência implicando a participação em outras formações familiares. 
Há também aspectos afetivos de sua relação com esses parentes com quem convivem em seu cotidiano doméstico que merecem destaque. Em muitos depoimentos, o modo como descrevem sua relação com os parentes tem uma tonalidade hostil, por vezes ressentida, em particular no que diz respeito à mãe, porém eventualmente atingindo outras pessoas:

Eu não tenho afinidade com a minha mãe. [...] Eu saí da casa da minha mãe muito cedo. Minha mãe me falou uma palavra que eu guardo até hoje. Eu tenho aquela coisa com ela. Ela falou [...]. Eu pedi uma coisa pra ela, e ela foi e falou: "Tem que pedir pro teu macho. Tem que pedir pro teu macho. Ele que tem que te sustentar." Pensando que eu era mulher e eu era virgem ainda. Eu nunca tive vontade de perder a virgindade. Eu perdi, porque eu fiz por fazer. Eu não tinha aquela vontade de perder. Eu fiz mais por causa dela: "Vou fazer pra agora ela falar com razão." Aí fui e saí da casa dela.

As duas primeiras características - a variabilidade/instabilidade na composição familiar e nos locais de moradia - definem um traço muito acentuado da trajetória comum no universo pesquisado: a não centralidade da relação pai/ mãe-filho(a) como critério de definição da formação familiar e da residência de que o jovem fará parte. Esse traço parece evocar o padrão de "circulação de crianças" identificado por Fonseca (2006, p. 13) junto a famílias de camadas populares em Porto Alegre, padrão esse que, em sua análise, se define como "a transferência de uma criança entre uma família e outra, seja sob a forma de guarda temporária ou de adoção propriamente dita". Se, contudo, acrescentamos ao quadro a terceira característica do universo aqui analisado, a semelhança parece se reduzir a uma "empiria mínima" - a experiência de ser criado(a) por pessoas outras que não aquelas da própria família biológica -, com a vivência subjetiva dessa "circulação" que encontramos aqui parecendo ser de natureza distinta.

A descrição de Fonseca da "circulação de crianças" abrange a discussão das motivações para a "doação" da criança e dos conflitos provocados por essa prática familiar. Entre as motivações, o "bem-estar" da criança ocupa lugar central, com sua "entrega" sendo muitas vezes vivenciada como um "sacrifício" feito pela mãe biológica. Entre os conflitos, destacam-se a disputa pela criança, o que, em sua versão "positivada", se traduziria na criação de vínculos entre as famílias envolvidas.

Disso emerge uma impressão geral de que tudo se faz em nome do bem-estar da criança. Dar a criança para ser criada é uma abnegação, um sacrifício 
da mãe que reconhece (supõe?) a própria insuficiência; a criança é recebida como se fosse uma "dádiva", estabelecendo vínculos entre a mãe "biológica" e a mãe "de criação", ocasionalmente abrangendo também redes mais extensas de parentesco. A criança, assim, surge como a maior beneficiada: sua entrega pela mãe que a "ganhou" não é um abandono, mas sim um sacrifício pelo seu bem-estar, e nesse movimento ela ganha uma segunda mãe, ao invés de perder a primeira. A criança do modelo de circulação descrito por Fonseca parece ser assim uma criança desejada por todos e que tem, neste modelo de responsabilidades compartilhadas, várias famílias.

A experiência afetiva dos jovens de nosso universo, contudo, não parece ser essa. O relato abaixo, de um rapaz de 17 anos, produz uma impressão nítida de uma vivência emocional distinta. O rapaz mora com um tio e sua família, explicando que não mora com a mãe porque o atual marido desta só a havia deixado levar sua irmã. Na sequência de seu depoimento, o rapaz acrescenta:

E seu tio te ajuda? Te dá dinheiro?

Não. Quem me dá um dinheiro é meu outro tio, irmão da minha avó. Ele faz comida lá, e me chama pra comer. Eu não gosto muito de comer aqui [na casa do tio em que ele mora, irmão da mãe] que meu tio fica jogando na minha cara. Eu fico mais é na casa da minha amiga T. Minha mãe às vezes também me dá dinheiro, quando ela tem.

A impressão é de que, nesse caso, a divisão de responsabilidades - um tio dá moradia, outro tio entra com a comida, a mãe ocasionalmente, dinheiro produz no rapaz um sentimento de que ninguém é plenamente responsável por ele. Experiência bem distinta parece ser aquela da menina que, deixada pela mãe ainda bebê com uma amiga para que dela cuidasse na praia, foi amamentada pela irmã dessa amiga. Segundo Fonseca (2006, p. 24):

[...] a própria menina, interrompendo suas brincadeiras para vir me falar, parecia encantada com o grande número de mães que ela tinha: "Três", ela explicava. "A mãe de leite, a mãe de criação e a mãe que me ganhou."

Ou seja, no universo de Fonseca, tanto no caso dos vínculos estabelecidos pela "dádiva" da criança quanto no caso das disputas por sua "posse", o problema parece ser que todos querem a criança, enquanto que, nessa fala-síntese da experiência típica dos jovens de nosso universo, ninguém a quer.

Horizontes Antropológicos, Porto Alegre, ano 20, n. 42, p. 327-357, jul./dez. 2014 
De um lado, responsabilidades compartilhadas, com uma resultante afetiva da percepção de, ao ser cuidado por várias pessoas, ter várias mães; de outro, responsabilidades delegadas, com uma resultante afetiva de, ao ser cuidado por várias pessoas, não ter ninguém.

\section{Os jovens e suas redes: escola, trabalho, comunidade}

Na socialização primária desses jovens, há outra experiência "anômica": a relação com a escola, tingida por deserções precoces e supostamente desastrosas:

Por que você parou?

Eu fiquei chateado de só me esforçar, me esforçar, tirar nota boa e ninguém reconhecer. Minha mãe nem ligava se eu tava tirando nota boa, se era bom aluno. E também foi na época que eu me descobri [homossexual], aí deu muita confusão e eu resolvi parar.

O trecho anterior, embora curto, é eloquente de uma trama que envolve a negligência materna, a admissão de uma condição vivida como estigmatizante (descobrir-se homossexual) e o não reconhecimento do esforço para ir bem na escola. Aliada a essa experiência de desamparo, as muitas confusões parecem determinar uma escolha feita de modo compulsório (o que pareceria uma contradição em termos). O depoimento segue:

E você gostava do colégio?

No começo eu gostava, mas eu não me dava bem com a turma.

Por quê?

Ah, tinha uns moleques que gostavam de brigar e eu não queria brigar.

Mas eles mexeram com você?

Às vezes eles implicavam sim, com esse meu jeito [homossexual]. [...]

E você não falava com a coordenação?

Eu não. Não ia adiantar nada, [...] tudo parente de traficante e a diretora tinha é medo deles. Eles faziam o que queriam na escola e ninguém falava nada.

E você não pensa em voltar a estudar.

Penso, mas agora eu não quero. Ano que vem vou ver se volto.

Se a negligência da mãe e a sexualidade estigmatizante compõem uma circunstância desfavorável ao prosseguimento na vida escolar, o próprio ambiente da escola conspira para a evasão. $\mathrm{O}$ tom resignado do depoimento 
reitera as várias vias que concorrem para a exclusão: o pai ausente, a mãe displicente, a escola que não acolhe, o tráfico que tiraniza (ainda que indiretamente) e a homossexualidade experimentada como inadaptação. Um retorno é aventado em futuro incerto, situado no próximo ano apenas como que prestando contas ao entrevistador.

Nesse depoimento podemos divisar alguns mecanismos que empurram precocemente os jovens mais pobres para fora da escola. No caso específico em questão, o desempenho não é o que pesa (cabe lembrar que é o baixo desempenho escolar que a literatura costuma identificar como um dos mais terríveis e determinantes mecanismos de evasão). Ainda assim, aparentemente temos um caso em que as dinâmicas internas da instituição têm um peso no desenlace da trajetória do jovem. Outros depoimentos seguem rumo semelhante:

E o que fez você desistir?

Não foi bem desistir. Na verdade eu já estava cinco anos na escola direto. Aí desistia dois anos e passava um ano. Eu já tava muito tempo na escola, aí a diretora e os professores ficavam zoando com a minha cara. Ninguém gostava de mim. Aí acabou que eu arrumei uma confusão na escola e tive que sair da escola. Que confusão?

Eu bati num garoto por causa de brincadeira de tapinha. Aí a gente fala pra parar e não quer parar...

Mas chamaram a sua mãe?

Chamaram. Mas não foi pra conversar, foi pra me tirar da escola logo!

Mas antes disso chamavam a sua mãe?

Sim. Porque vira e mexe tinha reclamação minha na escola. [...]

E como ela reagia?

Ué, não tinha do que reclamar, porque eu, como sempre eu tava errado. Não adianta nada ela ficar debatendo porque não ia dar em nada.

Também nesse caso o jovem acaba evadindo-se precocemente da carreira escolar. Sua deserção está associada à forma como a escola conduz episódios reiterados de conflitos com colegas. Aqui, no entanto, o jovem aparece como agressor contumaz. Ao contrário do caso anterior, a mãe do jovem aparentemente não era indiferente: era chamada e comparecia à escola; procurava aplicar procedimentos de controle, punindo-o por sua conduta, ainda que não obtivesse resultados. A ação da mãe revela-se, então, inoperante, ainda que por razões diversas daquelas observadas no depoimento anterior. Há, também 
nesse depoimento, um sentimento de resignação: afinal, o jovem "estava sempre errado mesmo".

À medida que vamos cotejando diferentes discursos, percebemos matizes que vão da experiência traumática decorrente da estigmatização por certos tipos de comportamento, como nos dois trechos citados nessa seção, a outros, ainda mais extremados, em que o fracasso no desempenho escolar é explicitado, como no pequeno trecho a seguir.

Eu pensava que era burro, mas eu não sou burro não. Eu sou inteligente. Nego fala que é burro. Nego fala: "Seu burro!” Mas não é. Burro faz as coisas de errado. Burro pega um negócio e coloca as coisas onde não devia ficar.

O trecho acima flagra o caso típico do jovem que incorpora quase que completamente a incapacidade imputada por terceiros e localiza aí o nó que o leva a desistir de sua vida escolar. O gradiente, contudo, pode nos levar ao sentido oposto, onde a evasão vai lentamente deixando de ser algo traumático ou mesmo problemático, ainda que situações envolvendo agressões e violência estejam aí implicadas.

A combinação apresentada a seguir junta mau desempenho, enfado, brigas e conflitos com colegas. Nada que soe especialmente dramático para o jovem ou para o convívio familiar, em que as figuras materna e paterna se revelam presentes:

Você está estudando?

Não. Larguei ano passado, no final do ano, mas já ia repetir mermo. [...]

E por que você parou?

Ah, eu não tava gostando não, das professora, das matéria. E também arrumei briga lá e a diretora me mandou ficar em casa. Aí eu resolvi não ir mais. [...]

E seus pais foram chamados?

Foram.

Eles fizeram o quê?

Nada. Minha mãe reclamou um pouco mas não fez nada não.

E você foi fazer o que depois que largou a escola?

Nada. Meu pai às vezes me chamava com meus irmão pra gente virar laje mas só de vez em quando. [...]

E seus pais iam nas reuniões do colégio?

Não lembro. Acho que minha mãe ia.

E qual a lembrança boa que você tem da escola?

Do recreio. 
Nesse último caso temos, então, uma experiência escolar em que para além do recreio nada parece ser muito interessante. $O$ jovem segue a vida "virando laje" com o pai e aparentemente se sentindo desobrigado do fardo escolar.

É interessante destacar que nenhum dos entrevistados desse grupo relatou qualquer passagem pelo chamado "mundo do crime". Isso não é suficiente, no entanto, para a invalidação da tese de que a evasão escolar os projeta numa condição marginal e de risco. Em seu entorno esse risco é apresentado como algo plausível e assustador:

\section{E você resolveu abandonar? \\ É. \\ E sua mãe disse o quê?}

Brigou pra caramba. Disse que eu não ia dar em nada e que ia acabar virando traficante, só por causa que eu tenho uns colegas que são "bandido". Mas eu não dou mole não.

A maior parte de nossos entrevistados apresenta o absenteísmo escolar como provisório e a interrupção como temporária. Quase todos cogitam retornar e, assim, viabilizar projetos bastante díspares, contraditórios e, à primeira vista, infactíveis. Independentemente dessas marcas discursivas, vale insistir na variação dos tons dos relatos, que vão do sentimento de capitulação diante de um cenário hostil à completa indiferença. Esta última aparece no relato de nossa entrevistada, cujo depoimento já foi destacado anteriormente:

Eu parei de estudar... Quando eu estudava, eu estudei... Fiquei na escola e estudei até a sexta série, mas parei. Fui me desligando da escola, porque eu andava muito. [...] Meus pais pagavam uma pessoa pra me levar pro colégio. Meu pai me ajudava. Ele era um excelente pai. Fazia dever de casa, fazia tudo. Eu sempre gostei de estudar. Agora depois de velha que eu repeti. [...] Eu zoava muito. Eu entrava na sala assim e pensava que tava chato. Aí saía pra fora aí chamava todo mundo. Todo mundo ia pro aeroporto. Ia pra shopping. Aí eu roubava o shopping.

Aqui temos uma jovem que relata algum cuidado dos pais quanto à sua frequência à escola, uma relação nada traumática com esse espaço para além do tédio que lhe proporcionava, e, em tom de brincadeira, a associação entre evadir da escola e cometer alguns pequenos delitos. 
É possível extrair algo que articule esses fragmentos sobre trajetórias e evasão escolar? Acreditamos que sim. Em todos eles a escola está longe de revelar-se um espaço positivo de socialização. Seu ambiente é hostil ou entediante, sua rotina enfadonha e sem muito sentido. Em todos os casos, a escola parece ter ejetado esses jovens, por omissão ou incapacidade de acolhê-los. A evasão parece significar libertação de um fardo ou de sofrimento. Por outro lado, a perspectiva de retorno raramente é descartada. Na maior parte das vezes ela faz parte de planos um tanto difusos e imprecisos.

\section{Projetos versus sonhos: concepsões de temporalidade e causalidade}

As narrativas impressionam pela vagueza. A sensação geral é de trajetórias erráticas, não planejadas, em que os acontecimentos e mudanças se sucedem sem intencionalidade, muitas vezes não apresentando também qualquer preocupação com explicações causais. As narrativas não seguem um padrão linear, com os acontecimentos narrados sem sequência cronológica, sugerindo uma percepção da temporalidade que não se mede em dias, meses ou anos em sucessão, prescindindo dessa forma de "marcar o tempo" para construir sentido. Alguns exemplos:

Depois que eu fiquei com o menino do [nome de morro], eu fiquei com o D. Depois do D., eu fiquei com o pai da minha filha. Aí eu fiquei com o pai da minha filha e engravidei dela. Aí quando eu engravidei dela. Antes, eu já tinha saído com ele, com o daqui [o atual dono da favela]. Aí ele foi e a gente ficava escondido, entendeu? Aí depois eu fui, e depois a gente separava. Aí eu fiquei com o pai da minha filha. Aí eu engravidei do pai da minha filha. Aí depois eu voltei pra ele. Aí ele não deixava mais o pai da minha filha pisar aqui. Aí eu fui e fiquei com ele.

Então você tá quase terminando o segundo grau?

É. Já parei duas vezes ou três vezes. Nem me lembro mais. Eu já estudei em três escolas diferentes. O primeiro ano, aí parei e depois voltei pro segundo ano, aí parei.

Essa forma de relação com a temporalidade, marcada pela natureza errática tanto das trajetórias quanto da forma de narrá-las, parece guardar relação com outro aspecto dos depoimentos que reforça ainda mais esta impressão geral 
de vagueza: a forma como os entrevistados(as) falam sobre seus projetos de vida. Listamos a seguir um conjunto de depoimentos, retirados de seis entrevistas distintas, para em seguida destacar os traços que suscitam essa impressão.

Que profissão você quer seguir?

Advogada. Meu sonho. Ser advogada criminalista. Igual ao meu pai.

Você tem vontade de trabalhar com quê?

$\mathrm{Eu}$, vontade de trabalhar? Telemarketing, e queria fazer um curso de enfermagem.

E sobre o futuro você vai terminar seus estudos, né?

Vou porque me amarro em cozinhar e se Deus quiser vou abrir um restaurantezinho, eu gosto de confeitar bolo, esse negócio de culinária.

E quais são seus planos pro futuro?

Estudar, fazer um curso bom. Trabalhar. Queria fazer um curso de informática e um de inglês. Porque aqui, eu preciso de muito conhecimento também pra trabalhar nesses hotéis aí, atendendo as pessoas assim.

E você não pensa em voltar a estudar.

Penso, mas agora eu não quero. Ano que vem vou ver se volto.

E você não pensa em voltar?

Penso, mas minha mãe tem que me matricular ano que vem. Por enquanto tô descansando.

Os entrevistados relacionam diversos planos para o futuro, em particular nas áreas da escolaridade e do trabalho. Esses projetos, contudo, são regidos pela imprecisão e, em particular, pela aparente inexistência de um vínculo de causalidade entre presente e futuro, uma vez que as atitudes e escolhas do momento presente não parecem guardar relação com a concretização de seus projetos. É assim que vemos um projeto, tal como ser advogada, formulado por uma moça que está fora da escola no momento da entrevista, ou projetos profissionais de naturezas muito díspares aparecerem como opções no mesmo depoimento (telemarketing e enfermagem, motorista de ônibus e comerciante).

Não se trata, evidentemente, de afirmar aprioristicamente a inviabilidade "empírica" desses projetos. Queremos destacar que os entrevistados não parecem (ao menos segundo seus relatos) pautar suas decisões e atividades

Horizontes Antropológicos, Porto Alegre, ano 20, n. 42, p. 327-357, jul./dez. 2014 
de curto prazo por projetos de médio ou longo prazo, estabelecendo articulações entre estas opções profissionais. Embora os entrevistados em sua maioria afirmem pretender voltar a estudar e estabeleçam alguma relação entre a educação formal e a consecução de seus planos, essa relação parece surgir no plano ideal, não tendo força suficiente para pautar as decisões de curto prazo, como voltar efetivamente a estudar, como indica a fragilidade das razões para estarem ausentes da escola (a clareza do "agora não quero, ano que vem vou ver se volto" ou, naquele que é talvez o mais sintomático dos depoimentos, "agora estou descansando").

Esses traços fazem com que a impressão geral causada por esses projetos seja de sonhos. A própria expressão "sonho" aparece ocasionalmente nos depoimentos; entretanto, os entrevistados apresentam essas ideias inventariadas acima em resposta à indagação sobre seus planos. Enfatizamos aqui essa distinção porque se ambos, planos e sonhos, remetem a projeções do entrevistado quanto a seu futuro, um "plano" supõe certa forma de vinculação entre o presente e o futuro em que a expectativa futura pauta as atitudes e decisões do momento presente, enquanto que a noção de "sonho" nos remete a um plano imaginário em que algo parece possível, porém independe das atitudes do narrador ("se Deus quiser vou abrir um restaurantezinho").

Velho (1981) discute a noção de "projeto" nas sociedades complexas a partir da fenomenologia de Alfred Schutz. Nessa concepção, um projeto seria uma "ação com algum objetivo predeterminado" (Velho, 1981, p. 26, grifo do autor). A preocupação de Velho tem, como questão teórica de fundo, a análise da experiência subjetiva contemporânea, articulando as dimensões individual e social. Com isso em mente, formula a noção de "campo de possibilidades", que seria aquilo que confere inteligibilidade e mesmo viabilidade, do ponto de vista sociocultural, a um projeto individual, uma vez que, para ele, "a própria condição de sua existência é a possibilidade de comunicação (Velho, 1981, p. 27, grifo do autor). Recorrendo à obra de Basil Bernstein, Velho atenta para a articulação entre linguagem e temporalidade, afirmando a distinção entre projetos verbalizados e não verbalizados, em uma diferença que diz respeito à consciência do ator social. Nesse sentido, caberia, ainda para Velho, distinguir entre "projeto" e "fantasia". Essa distinção, que o autor declara não explorar em seu texto, pode ser tomada como análoga à diferença que sugerimos entre "plano" (ou "projeto") e "sonho".

O ponto central aqui nos parece ser justamente esta aparente indistinção entre projeto e sonho, em que os entrevistados, ao descreverem suas escolhas 
e atitudes do presente, revelam agir de forma incongruente, de acordo com seu próprio entendimento, com aquilo que ambicionam, uma vez que, em outra dimensão, conectam sua realização a atitudes distintas daquelas que efetivamente adotam - como na relação entre o estudo formal e os projetos profissionais estabelecida por vários entrevistados. Essa incongruência, contudo, parece lhes escapar inteiramente à consciência.

Esse (não) estabelecimento de relações de causalidade entre atitudes presentes e resultados futuros não parece causar qualquer desconforto nos entrevistados, sendo, em alguma medida, plausível (pelo fato em si de poder surgir como uma resposta viável nas entrevistas). Essa relação com a temporalidade nos sugere uma aproximação com o universo dos meninos de rua de Silva e Milito (1995).

Em sua etnografia, os autores esboçam algumas relações entre o trabalho de campo com os meninos e outra etnografia realizada junto a outro grupo cuja relação com a "rua" e a "transgressão" é também uma marca registrada: as travestis da Lapa (Silva, 1993). Duas são as relações que nos interessam aqui: as particularidades da relação com o tempo próprias de cada universo (a inversão noite-dia para as travestis, o "gasto" despreocupado e errante do tempo no caso dos meninos) e o lugar concedido à mentira como um tipo de dado presente no trabalho de campo.

Silva (1993), discutindo as histórias fabulosas que lhe foram contadas como episódios reais de suas biografias pelas travestis (viagens e casamentos na Itália com príncipes donos de castelos magníficos), recupera o valor dessas "mentiras" para o trabalho etnográfico abrindo mão do desvendar de uma "verdade empírica" como objetivo da pesquisa. Em seu lugar, a mentira como sonho, ou seja, aquilo que revela, através daquilo que sonho ser, mas sei que não sou, aquilo que de fato sou. Afinal, não contamos todos as mesmas mentiras, nem sonhamos todos com as mesmas coisas...

Os meninos de rua "mentem" também, sobre "uma mãe remota, [...] parentes perdidos, [...] uma origem da qual não se lembram, o olhar distante, lacrimoso a perseguir esse menino, essa infância triste construída em nossa consciência culpada" (Silva; Milito, 1995, p. 170). A exemplo da etnografia sobre as travestis, a "mentira" do menino de rua não é descartada como informação falsa que oculta o real que se quer descobrir: é, ao invés, entendida como "mecanismo de fabulação", como uma forma de pensar sobre o real que revela esse mesmo real. 
A equivalência de nossos entrevistados entre o "sonho" e o "projeto", sua aparente indistinção que não parece causar qualquer incômodo ou mesmo ser notada, poderia assim ganhar sentido como via de acesso a uma dada forma de compreensão da própria trajetória, narrada sem maiores preocupações com cronologias oficiais porque justamente não se pauta por suas expressões, tais como os calendários ou periodizações escolares, ou por suas causalidades, tais como a obrigatoriedade de um vínculo entre a educação formal e a inserção no mercado de trabalho. Uma dupla errância, biográfica e narrativa: é esta percepção alternativa da temporalidade que nos parece oferecer um caminho para que a aparente "irrealidade" de seus planos se configure como via de acesso para a compreensão da "realidade" vivida pelos jovens entrevistados.

Vejamos, agora, como essa mesma errância pode ser flagrada nas experiências com a violência e na maneira como nos são narradas.

\section{Experiências e percepsões da violência}

Já há alguns anos as abordagens sobre a criminalidade violenta têm reservado um espaço importante para os problemas relativos à infância, à adolescência e à juventude (Soares, 2000; Zaluar, 1994). As razões são óbvias. Como já foi dito, a faixa etária é um fator de risco consistente. O caso brasileiro revela-se especialmente dramático em função das grandes taxas de criminalidade violenta com que o país tem vivido nas últimas décadas. Algumas pesquisas e análises que arriscam orientações propositivas para lidar com o problema costumam desenhar o seguinte quadro: aos apelos simbólicos e materiais oferecidos pelo mundo do crime (a inserção nos grupos varejistas de tráfico de drogas costuma ser a principal referência) deve-se contrapor a abertura de um leque de oportunidades que se mostrem tão ou mais atrativas para os jovens moradores de favelas e periferias (Dowdney, 2003; Soares, 2000).

Tudo leva a crer que o diagnóstico procede e a prescrição deve ser encarada, no mínimo, como moralmente defensável. A questão analítica que se coloca, contudo, é a percepção do que exatamente significa estar dentro ou estar fora do chamado mundo do crime. Se cabe ao poder público e demais instâncias competentes "disputar" adolescentes e jovens com o crime, estamos autorizados a supor que a entrada implica graus de comprometimento e integração que devem ser evitados e/ou cortados de modo contundente e definitivo. Supõe-se, igualmente, que estar fora representa a supressão ou evitação 
efetiva de que tais laços sejam estabelecidos. A pergunta que cabe ser feita para qualificar o argumento é sobre a natureza desses laços, tal como são experimentados por aqueles sobre quem falamos.

A julgar por vários depoimentos coletados, a experiência com o "mundo do crime" é ambivalente. Tomar ou não parte desse universo pode ser experimentado por não poucos jovens de uma forma bem menos esquemática do que podemos supor:

\section{Já foi pega?}

Já. Mas não fui presa, não. A última vez que... eu parei de roubar. Eu apanhei pra caramba. [...]

Como os policiais te tratavam na delegacia?

Eu só ficava lá. Nunca me bateram não na delegacia. Queriam chamar a minha mãe.

Talvez para a entrevistada ser "presa" envolva julgamento, cumprimento de pena e algum tempo de detenção no sistema carcerário. Por outro lado, ser "pega" significa apanhar, ser detida em uma delegacia, ser alvo de ameaças de policiais, mas não é o mesmo que ser "presa". As ameaças sofridas podem chegar a ter a mãe chamada a comparecer à delegacia.

Do envolvimento com práticas "mais brandas" como o furto, passemos à mais complexa proximidade com o universo do tráfico:

Tráfico, não. Eu já namorei. Meus namorado é tudo traficante. [...] Aí eu namorei ele. Ele me sustentava, me dava as coisa. Depois eu larguei ele. Aí eu larguei ele e fiquei com um menino daqui. Fiquei com o D. Já tá morto já. Ele era dono daqui, da [nome da favela].

O simples fato de "apenas" namorar traficante, contudo, confere certo senso de pertencimento ao grupo. O envolvimento é de ordem afetiva, mas não exclui um grau relativamente denso de estar dentro:

Aí ele foi e me chamou pra fazer esporte na Vila Olímpica. Fazer natação. Aí eu falava: "Tá maluco? Não posso passar pra lá, não." Porque, aqui, sempre teve guerra com lá. ${ }^{3}[\ldots]$ Eu era envolvida também. Eu era envolvida com traficante, eu não podia passar pra lá.

3 “Lá” se refere a uma região da favela sob domínio de outra facção criminosa. 
Um dado importante que tem chamado a atenção de analistas é a relação simbólica com armas de fogo. Signo de poder e virilidade, portar uma arma pode ter sentidos variados e contingentes. Sua ausência absolve ou pode minimizar certas condutas. Sua presença não necessariamente culpabiliza. Os dois relatos a seguir tomam direções diferentes sobre o tema, mas convergem no peso e relevância para a questão:

\section{Você roubava à mão armada?}

Não. Roubava pisa. Tipo... vai com a bolsa, joga um montão de coisa dentro da bolsa e traz pra aqui pra vender tudo. [...] Quando eu tomei a porrada, foi a última vez que... aí eu falei: "Não quero mais."

\section{Ele tava armado?}

Tava armado. E a polícia viram que no lugar que ele tava, tem um barzinho. Viram que os caras enquadrou ele, botaram dentro do carro da polícia e tudo. [...] Aí chegou no outro dia ele tava lá no [...] em São Gonçalo. [...]

Alguma vez você se envolveu com algum crime?

Se envolver, se envolver, nunca cheguei a me envolver não. Mas conheço gente, já vi de perto. Segurei arma já e tudo. Então, quero evitar contato com a polícia. A gente vê gente... O meu primo morreu. Se eu visse quem matou ele e eu pudesse matar, eu matava, sinceramente. Pô, meu primo... Eu sabia que ele não era bandido, não era nada. Os cara traíra. Nem pegam a maioria que tá por aí.

No primeiro fragmento, não fazer uso diretamente de armas parece conferir, para a entrevistada, certo atenuante aos episódios. Eles são relatados quase como brincadeiras, traquinagens lúdicas e sem maiores consequências até a experiência traumática de tomar uma "porrada", o que interrompe a articulação ao lúdico e a faz desistir de tomar parte dos roubos. Se no primeiro relato a ausência de arma absolve, projetando os episódios relatados em uma quase diversão, no segundo ela é tratada como insuficientemente contundente para a criminalização. $O$ trecho introduz um relato sobre a execução, por policiais, de um parente do entrevistado. $\mathrm{O}$ referido parente estava armado, foi detido e quando todos pensavam que seria encaminhado para a delegacia, seguindo o rumo natural (ao menos em tese) dos eventos, simplesmente desaparece, sendo encontrado morto horas depois. Em tom de revolta pela morte do parente, o jovem alega jamais ter se envolvido em qualquer atividade criminosa, complementando, contudo, com uma conjunção adversativa (mas), que conhecia pessoas ligadas a atividades criminosas e já segurara uma arma. 
O peso do contato com a arma, deflacionado quando alegara que portar uma arma não seria motivo para a detenção do parente, reaparece quando de sua própria experiência.

É pouco provável que haja experiências tão radicalmente associadas à violência como aquelas relacionadas à morte intencionalmente provocada a terceiros. Também sobre isso os relatos oscilam entre o impacto e a naturalização, com sentidos variados emergindo em cada depoimento em que o tema aparece:

Muita coisa. Já vi muita pessoa morrendo. Já teve muita coisa. Um morreu aqui. Eu vi aqui atrás. Esse foi todo cortado. Eu vi tudinho. Foi morto por bandido daqui que já morreu. Falaram que ele estuprou uma garotinha. Falaram que ele abusou da garotinha. Aí foi e cortou ele todo. Vivo. Aqui atrás. Vi uma menina também que saiu com polícia. Falaram que ela tava com polícia. Vi ela morrendo.

Aí eu fui e fiquei com ele. [...] Aí depois ele morreu.

Morreu como?

Morreu com os polícia que matou ele. Caguetaram ele. Aí na hora que ele tava saindo de uma casa, ali na principal, os polícia pegou e enquadrou ele. Aí ele não queria entrar na viatura. Não queria, não queria. Ele era imenso. Ninguém podia segurar ele. Ele não queria entrar, não queria entrar. Os policiais já ia matar ele já. Aí foi, deu quatro tiros nas costas dele pra ele entrar. Aí ele entrou, mas não tinha morrido ainda não. Aí levaram lá pro pinheiro e mataram ele lá na mata.

Outro entrevistado relata, ainda seguindo na linha das ambivalências:

O lugar que você mora com a sua avó é um lugar tranquilo?

É.

Tem muita briga, ou muita discussão na rua?

Tem não. Às vezes aparece uns mortos lá, mas é difícil. Nem escuto tiro.

Você já conheceu alguma dessas pessoas mortas?

Não. Aparece... Mas é raro aparecer. Mas de vez em quando aparece.

Os extratos mencionados anteriormente foram retirados de entrevistas de jovens moradores de favelas ou de bairros pobres. Nenhum deles cumpria ou cumpriu medida socioeducativa ou qualquer outra sanção por violação da lei. Todos, no momento em que foram entrevistados, estavam fora do sistema 
escolar, do qual saíram antes de completar o ciclo de ensino básico ou médio. Carregam em seu perfil traços compatíveis àqueles que são atribuídos às situações de risco e efetivamente estiveram dentro e fora, na maior parte das vezes de modo simultâneo, do mundo do crime. Os relatos, contudo, sem negar ambas as noções, embaralharam um entendimento do que isso significa. Estar e não estar simultaneamente parece uma condição de suas próprias vidas, um pouco por escolha, um pouco por contingências. Qual a imagem de suas trajetórias que essas experiências desenham?

\section{Primeiro arremate}

Errâncias, imprecisões, ambivalências: esses termos parecem dar a tônica dos relatos. Perguntados sobre suas trajetórias familiares, falam de famílias múltiplas, eventualmente coexistentes no tempo; contam sobre vivências "nômades", sem habitação fixa; revelam um sentimento em que o responsabilizar-se não é função de um papel socialmente definido, mas parece se dar de forma aleatória, ditada não por critérios macrossociológicos de organização social, mas ao sabor dos desejos e personalidades individuais.

Observadas de um ponto de vista sociológico, essas trajetórias não parecem apresentar um padrão. "Vício" teórico de uma disciplina comprometida com a busca de recorrências subjacentes a experiências vividas como singulares? Sem dúvida. Comprometidos, ainda que conscientemente, com esse paradigma, encontramos na noção de "circulação de crianças" de Fonseca (2006) um apoio para identificar o "padrão". Esse padrão, contudo, parece não combinar com a particularidade da vivência afetiva dos entrevistados, que, ao invés de "disputados" porque queridos por muitos, são "delegados" porque indesejados por todos.

Os vínculos escolares são igualmente instáveis, continuamente interrompidos, dando, tanto no plano da realidade extrínseca ao qual o relato se refere quanto na própria forma de narrar, uma impressão de errância, em que projetos e sonhos se confundem em um imaginário que não parece estabelecer as relações "oficiais" de causalidade (formação escolar $\rightarrow$ diploma $\rightarrow$ emprego formal) ou mesmo pautar-se pelo calendário oficial, vagando em um rememorar que não conta suas histórias de forma sequenciada em dias, meses ou anos comprometidos com datas precisas. 
Sua relação com o mundo do crime também não parece, de uma forma cuja coerência não deixa de soar aqui como ironia involuntária, ser ditada pelas categorias oficiais de "legal/ilegal"; escapa a tipificações, "jogando" astuciosamente com o mundo da lei, seja manipulando-o (a recusa a dar o nome), seja ressignificando-o (a trivialidade dos braços avermelhados), seja deslizando entre várias implicações (a arma que ora caracteriza uma relação com o crime, ora não porta qualquer significado digno de intervenção policial). Brincadeira, traquinagem, transgressão, crime: essas categorias parecem consistir em um continuum de fronteiras difusas, em que o personagem pode facilmente escorregar de um termo a outro, muitas vezes para sua própria surpresa, em um processo que lembra aquele descrito por Katz (1988) ao comentar o espanto dos jovens que se viam enquadrados juridicamente como "ladrões" por terem cometido furtos vivenciados como uma forma de travessura.

Tantas errâncias e ambivalências parecem nos sugerir a relevância de desconfiarmos, conforme sugerido na introdução, das explicações matriciais que a tudo enquadram em relações de causa e efeito. A curiosa - e, para o reformador social, dolorosa - constatação de Tilley (2009), quando, relatando alguns resultados de pesquisas relativas a trajetórias de vida, percebe a fragilidade conclusiva dos fatores de risco para a explicação da prática reiterada de ações criminais, parece ser reforçada e parcialmente esclarecida nesses depoimentos. Neles, o plano dos afetos é multifacetado, assim como as formas de exclusão e inclusão em redes fronteiriças. A suposta linearidade do sujeito, apropriado quase despoticamente pela retórica sociológica, é implodida por idas e vindas, entradas e saídas, pontos de estrangulamento e de fuga.

\section{Trajetórias jovens e formas de institucionalizacão: uma análise de "instantâneos"}

A proposta de analisar quatro grupos de jovens (escolarizados; participantes do ProJovem; em cumprimento de medidas socioeducativas; e afastados de qualquer experiência institucionalizada) tinha evidentemente, no bojo de sua concepção, uma questão central: de que forma os vínculos institucionais, em particular com a escola, afetam as experiências e percepções dos jovens cariocas em relação à violência, tanto na posição de vítimas quanto na de agressores? Essa questão conduziu assim ao delineamento desses quatro grupos, cujas fronteiras evidenciam o lugar privilegiado atribuído 
à escola, na própria formulação das hipóteses, como eixo diferenciador destas trajetórias.

O processo de pesquisa, contudo, levantou dúvidas quanto aos tributos implícitos que essas questões originais estariam pagando às explicações matriciais canônicas dos estudos sobre criminalidade, já levantadas na seção anterior acerca dos relatos dos jovens afastados de experiências institucionalizadas. A análise dos relatos dos demais grupos, aqui empreendida, suscita um novo questionamento, desta vez acerca da própria categoria "trajetória", central na própria elaboração do roteiro das entrevistas: é possível "tipificá-la"? Ou, colocando de outra forma, seriam as fronteiras entre esses grupos estáveis o suficiente para nos permitir analisar trajetórias típicas determinadas pelas formas de institucionalização?

Parece-nos que não. Fomos por vezes surpreendidos em meio à leitura de algumas entrevistas pelo relato de episódios que nada até ali nos autorizaria a imaginar. O exemplo mais impactante foi o da entrevistada abaixo. Após narrar um desentendimento que tivera com uma professora por causa de sua maneira de fazer a borda de cartazes, a entrevistada, internada no Degase, conta assim a razão de sua institucionalização:

Por que você veio pra cá? A gente não falou sobre isso.

Ah, eu não gosto de falar sobre isso não.

É que é um pouco importante pra gente entender o que...

É que eu cometi o artigo $121 \ldots$

Eu não entendo.

Homicídio.

Dos conflitos em torno da estética de seus cartazes a uma internação por homicídio: o espanto diante dessa guinada em sua trajetória nos fez colocar em questão exatamente a adequação da noção de "trajetória", em especial em sua versão reificada para fins de definição das fronteiras entre os grupos. Afinal, alguns meses antes essa moça poderia ter sido entrevistada no grupo dos jovens escolarizados...

Como, então, reificar estas trajetórias, tratando-as como "tipos"? Nelas há muitos pontos de cruzamento, que nos exigem cuidado com demarcações excessivamente rígidas das fronteiras entre esses "grupos" de jovens, os quais, no limite, são fruto da nossa imaginação - imaginação sociológica, decerto, mas ainda assim imaginação, que deduz grupos e trajetórias típicas a partir de relatos que nada mais são do que instantâneos das biografias desses jovens. 
Estas ponderações são por ora apenas uma ressalva. A estrutura deste texto mantém o compromisso com o projeto original e separa, para fins analíticos, os "grupos" de jovens que estruturaram o processo de pesquisa. Assim, retomamos os pontos principais que destacamos na análise das trajetórias dos jovens à margem das formas de institucionalização e os transformamos em "perguntas" a serem feitas aos relatos produzidos pelos jovens dos outros grupos: como é sua família? Como foi sua trajetória escolar? Qual a relação que sua família mantém com sua escola? Quais são seus planos para o futuro? O que você pensa da violência urbana?

Ao final, contudo, em um exercício que a consequência intelectual exige de nós, retomamos essas provocações iniciais já não mais apenas como ressalva, mas para relacioná-las com as inquietações expressas na abertura da seção anterior acerca das articulações implícitas entre nossas perguntas/respostas e as explicações matriciais dos estudos sobre a criminalidade.

\section{Jovens em cumprimento de medidas socioeducativas: uma causalidade casual?}

Os relatos dos jovens em cumprimento de medidas socioeducativas têm uma característica discursiva recorrente: a natureza monossilábica das respostas, sugerindo um desejo recorrente de encerrar a entrevista. O contraste com a forma de narrar do primeiro grupo é gritante. Os jovens em cumprimento de medidas socioeducativas narram suas trajetórias escolares seguindo a sequência da organização do ensino, informando espontaneamente as mudanças de ciclo e associando-as à idade.

Os relatos sugerem por vezes uma percepção extremada da passagem do tempo, rigidamente controlada pela rotina institucional, em uma espécie de "hipercronometragem", como no exemplo a seguir:

A gente tem que acordar às 6 hora da manhã a gente forma, a gente tem que às 7 hora entra pra tomar o café, acabou de tomar o café a gente vai pra fila de novo, aí vai pra escola, aí sai vai pra escola, aí dá um intervalo na escola, 9h30, depois aí toca o sinal a gente entra pra escola. Quando dá 11 hora a gente forma pra almoçar, acabou de almoçar a gente forma pra entrar pro alojamento, dá $1 \mathrm{~h} 30$ sai pra escola, tem gente que estuda à tarde e gente que estuda de manhã, vai pra escola à tarde, quem não vai pra escola de tarde faz curso, aí $2 \mathrm{~h} 30$ dá intervalo da escola aí a gente sai, 15 minutos a gente volta, aí 4 hora a gente forma e vai lanchar, depois do lanche a gente forma, entra, aí toma banho rapidinho,

Horizontes Antropológicos, Porto Alegre, ano 20, n. 42, p. 327-357, jul./dez. 2014 
dá 6 hora a gente janta aí acaba de jantar vai pra quadra, fica lá na quadra à toa, aí quando dá 7 hora a gente vai cear, quando acaba de cear, fica lá fora, quando dá oito hora a gente entra.

As composições familiares de que esses jovens fazem parte não revela a existência de qualquer padrão. Entre elas, há desde famílias nucleares tradicionais, em que pai, mãe e irmãos coabitam, até formações semelhantes àquelas encontradas no primeiro grupo. O padrão do "pai ausente", apontado como uma variável fundamental nas trajetórias desviantes por tantas sociologias e psicologias, não pôde ser identificado nessas entrevistas.

Esse conjunto de relatos nos sugere ainda a necessidade de atentarmos para outro aspecto das relações familiares: a possibilidade de convivência de uma organização familiar "estável”, tal como preconizam tantas moralizações, com uma experiência de isolamento cotidiano dos pais. $\mathrm{O}$ fragmento abaixo é muito eloquente a esse respeito:

Mas por que você faltava?

Não dava vontade de ir pra escola, eu vivia na rua com meus colegas.

Mas você não gostava de nada na escola? Não tinha nada?

Não, não é que eu não gosto de escola, é que eu não gosto de ir pra escola, quando era de manhã, eu não ia porque tinha preguiça de ir, de tarde eu não aguentava por causa do sol, aí eu não ia.

Fala um pouquinho pra mim como é que é esse se dar bem com os seus pais?

Eu me dou bem, só que a gente não conversa muito, a gente não é de conversar, a minha mãe é muito fechada e meu pai trabalha muito. Lá em casa eu ficava mais conversando com meus irmãos, o mais velho. [...]

Sua irmã trabalha?

Trabalha, minha irmã de 21 é professora.

E a outra?

A de 19 trabalha na fábrica.

E o que você conversava com elas?

Conversar a gente ficava conversando e eu contava um monte de coisa da minha vida, e elas sabiam de tudo que eu fazia, só pra minha mãe e pro meu pai que eu não contava, então eles nunca sabiam da minha vida.

Essa entrevista aponta já o caminho do tipo de relação com a escola que predomina nesse grupo. A entrevistada aponta, como razões para não ir à escola, "preguiça" (para ir de manhã) e "sol" (para ir de tarde). Essas razões sinalizam para a tônica dessa relação, que passa ao largo de considerações de natureza 
acadêmica (ausência/qualidade dos professores ou dificuldades de aprendizagem) ou mesmo envolvendo aspectos do cotidiano escolar (violência ou infraestrutura deficiente). O tipo de lembrança que os entrevistados contam guardar de sua vida escolar vem confirmar essa forma de relacionamento com a escola:

O que você mais gostava na escola?

Meus colegas. E a gente zoava muito dentro da escola. Uma vez tacaram uma bomba perto de mim dentro da escola.

Você podia contar pra mim uma lembrança que você tem da escola? Ah, quando eu comia muito.

Você tem alguma lembrança de quando você ia à escola? Nenhuma.

Essas são suas lembranças da escola: "zoação", comida ou, exemplarmente, nenhuma.

De maneira muito sintonizada com essas lembranças, os relatos incluem entre as motivações para largar a escola um sentimento de "enjoo":

Mas por que você não gostava da escola, tinha algum motivo?

Sei lá.

Você gostava? Gostava de alguma coisa da escola?

Gostava, mas eu num... enjoava, sei lá.

Por que você desanimou?

Eu tava meio enjoada de estágio. Tava enjoada principalmente de muito trabalho, estágio, eu tava assim... também namorava e me atrapalhava muito, me questionava, eu sempre podia... não tinha muito tempo pra poder passear, não tinha tempo pra namorar, essas coisas assim, aí era muito trabalho.

Esse "enjoo" como uma motivação para abandonar a escola é muito expressivo de uma maneira de compreender/explicar as razões por que fazem determinadas coisas. Perguntados sobre os atos que levaram à sua internação, os entrevistados falam de agressões que cometeram, de assaltos de que participaram, de vínculos com o tráfico de drogas. Instados a explicar o porquê de suas ações, oferecem explicações em que as motivações soam vagas ou mesmo inexistentes. Não se trata, evidentemente, de dizer que os entrevistados não tiveram motivações para agir do modo como fizeram, mas sim que 
suas atitudes são percebidas por eles e descritas como ocorrendo ao sabor das circunstâncias, sem que sejam relatadas reflexões e decisões que antecipem a ação. É uma forma de compreensão das relações de causalidade de seus atos marcada pela casualidade: uma causalidade casual. Vejamos:

A segunda agressão foi quando?

Foi na praça.

Motivo, por quê?

Implicância.

Porque meu vizinho sempre ia lá na minha casa, ele e a esposa dele. Então eles eram muito assim... aí ele me apresentou ele, aí a gente... eu tenho mania assim... sinceramente, eu adoro totó. Eu e os filhos dele faziam campeonato de totó. Aí uma vez a gente saiu eu, ele e o X, de carro, os filhos dele, todo mundo zoando. Aí na outra semana, quando eu saí com ele, que ele pegou quando a gente tava voltando, que eu pedi pra ele me deixar descer em frente de casa, ele: "Não, vamos dar uma volta...", ele assaltou o menino.

[...] Aí depois que eu comecei a usar droga eu conheci uma menina né, aí ela me chamou pra entrar no tráfico, só que eu não queria, aí eu falei quero ver como é que é, aí eu entrei.

Esse modo de compreensão das relações de causalidade aparece ainda sob outra forma, esta particularmente triste:

Seu pai continua te dando pensão? Mas nunca veio aqui, né?

Não, porque ele nunca nem me registrou ainda. $O$ cartório estava em greve.

Ele te conheceu aos 7 anos?

Sim.

Jovens escolarizados: uma trajetória default?

Família e escola: uma parceria

Este último conjunto de entrevistas tem como característica principal a impressão geral de estabilidade. Esse traço se anuncia de saída em seus depoimentos, no momento em que falam sobre sua composição familiar. Embora os arranjos possam variar, é comum a presença da mãe ou do pai, com combinações 
tais como um padrasto, irmãos, avós ou tios, ou, em casos mais raros, filhos. Entretanto, não é a presença recorrente de ao menos um progenitor em sua forma de morar que dá esta impressão de estabilidade, mas sim o fato de que os arranjos familiares não mudam, ou seja, a maior parte dos jovens relata sempre ter morado com aquelas mesmas pessoas, quaisquer que sejam elas.

Suas experiências com a escola guardam essa mesma marca de estabilidade. A quase totalidade dos jovens entrevistados é capaz de dizer com que idade e/ou em que série começou a frequentar uma escola, bem como de narrar sua trajetória escolar. As razões para mudarem de escola são mencionadas, guardando relação com a seriação acadêmica do ensino, ou seja, esses jovens quase sempre mudam de escola por razões ditadas exclusivamente pela própria forma de organização das escolas: quando completam um ciclo acadêmico e a escola em que estão não oferece o ciclo seguinte. A seriação escolar impregna sua forma de narrar suas trajetórias escolares, que procede cronologicamente, ciclo a ciclo, escola a escola.

Um segundo traço que chama a atenção é a natureza das experiências que, incitados pelos pesquisadores, destacam como "marcantes". Ao contrário dos jovens em cumprimento de medidas socioeducativas, cujas lembranças mais marcantes da experiência escolar são a "comida", a "zoação" ou "nenhuma", os jovens escolarizados elegem episódios de sucesso, como um trabalho premiado, professores queridos, atividades extracurriculares ou dificuldades de adaptação ao ensino - ou seja, suas memórias acentuam a natureza acadêmica da experiência escolar.

Em meio aos relatos, há também lembranças marcantes de acontecimentos que, embora ocorrendo em ambiente escolar, não são de natureza acadêmica, como é o caso do acidente relatado a seguir:

Me conta alguma lembrança assim da sua vida escolar, alguma coisa que te marcou assim, algum momento...

De alegre ou triste?

Tanto faz. Alguma coisa que te marcou.

Foi quando eu quebrei a cabeça. Na minha outra escola.

Como que foi isso?

Eu tava jogando futebol, caí e quebrei a cabeça.

E aí você ficou no hospital muito tempo?

Foi, tinha seguro na escola.

Tinha o quê?

Tinha seguro. 
Essa é, sem dúvida, uma experiência excepcional. Entretanto, relatada pelo entrevistado em resposta à solicitação de uma lembrança marcante da vida escolar, ganha outras conotações. Se a experiência escolar desempenha, para esse grupo de jovens, uma função de "balizamento" de seu cotidiano e de sua trajetória, conferindo-lhe a marca da estabilidade, a inclusão espontânea pelo entrevistado da menção ao seguro da escola (que, por inusitada, suscita um pedido de confirmação pelo pesquisador), ganha aqui valor de metáfora, sugerindo que essa estabilidade pode, ao menos em ocasiões extraordinárias, promover um senso de segurança.

Há ainda um último traço da experiência escolar desse grupo que é digno de nota: o tipo de relação estabelecida entre suas famílias e a escola. A maior parte dos entrevistados conta ter sido matriculada pela mãe, descrita também como uma figura assídua, presente nas reuniões de escola e/ou ajudando com os deveres. O ponto-chave parece ser o interesse da mãe pelas atividades escolares, expresso de maneira particularmente nítida pelo jovem que conta que sua mãe não tinha tempo para ajudá-lo ou para ir às reuniões de pais, descrevendo-a, ainda assim, como presente porque ela "perguntava".

A questão central parece ser a existência de laços estreitos entre a família e a escola, uma vez que, mesmo no caso dos entrevistados que relatam impossibilidades de suas mães de se fazerem presentes em sua vida escolar, há sempre uma figura substituta - uma tia, uma irmã mais velha, uma avó - que supre essa ausência, eventualmente encarregada pela mãe.

Essas trajetórias escolares projetam, quase todas, um desdobramento comum: a intenção de cursar uma faculdade. A maior parte dos entrevistados tem já uma carreira de predileção. Em alguns poucos casos, essas escolhas são detalhadamente comentadas, vindo acompanhadas de justificativas elaboradas. Em um ou outro relato há também exposições mais detalhadas sobre o modo como o entrevistado avalia suas chances em um vestibular. No geral, contudo, essa pergunta, feita ao final da entrevista de acordo com o roteiro elaborado, suscitou respostas marcadas pelo laconismo. É como se esta fosse uma escolha default.

Violências: escola e comunidade, tráfico e polícia

Sobre suas percepções e experiências com violência, os relatos dos jovens escolarizados parecem reproduzir percepções e experiências que podem

Horizontes Antropológicos, Porto Alegre, ano 20, n. 42, p. 327-357, jul./dez. 2014 
ser encontradas junto a inúmeros outros segmentos no Rio de Janeiro. Alguns comentam formas de violência que ocorrem nas comunidades onde moram; outros distinguem entre a violência na favela e a violência no asfalto; há quem relate episódios em que foram vítimas de furtos sem uso de armas, ocasiões hoje já banalizadas no quadro da violência urbana carioca; uns poucos falam de episódios em que foram achacados por policiais ou comentam sobre arbitrariedades e agressões cometidas por policiais. Outros discorrem sobre a experiência de convívio com traficantes, que parece fazer parte de seu cotidiano sem suscitar maiores dilemas: o tom geral parece ser "viva e deixe viver", enfatizando o caráter de escolha dos amigos, parentes e conhecidos que se envolvem com o tráfico, porém sem tecer críticas mais contundentes a essas escolhas.

A experiência desses jovens com as várias formas da violência não parece assim apresentar qualquer marca específica que possa estar associada ao fato de serem jovens ou escolarizados. Completam assim a impressão geral que a leitura desse conjunto de relatos suscita: o de estarmos diante de uma "trajetória default", em que nada surpreende - cursam o ensino médio, pretendem fazer faculdade, suas famílias têm uma composição estável e se interessam pelos seus estudos e têm um temor brando e difuso em relação às várias formas da violência urbana com que se deparam em seu cotidiano, mas que não são muito distintas daquelas a que os adultos com quem convivem em seus locais de moradia estão também submetidos. Vidas regradas sem maior dramaticidade e que, por isso mesmo, pouco atiçam a curiosidade do sociólogo.

Mas por quê? Pouco temos a dizer sobre as trajetórias desse grupo, que se impressionam por alguma coisa é justamente por sua natureza "enquadrada" em expectativas normatizadas. Mas um objeto de pesquisa que não nos diz nada de novo diz, evidentemente, alguma coisa. O fato em si de não termos muito a dizer sobre eles, em contraste com a mobilização intelectual provocada pelas trajetórias dos jovens dos outros grupos, traz em si uma questão. O que essa impressão de "mesmice" tem a nos dizer sobre o próprio processo de pesquisa? Ou, parafraseando Bauman (1998) em sua análise sobre a relação entre a sociologia e o Holocausto: se as ciências sociais não têm muito a dizer sobre os jovens escolarizados, não será porque estes jovens têm muito a dizer sobre as ciências sociais? 


\section{Arremate final}

A análise dos jovens afastados das formas de institucionalização foi marcada pela preocupação em manter aberto o espaço para a problematização em torno do lugar a ser atribuído às três grandes matrizes consagradas pelos estudos dos comportamentos desviantes: a família, a escola, as perspectivas de futuro. Em que a análise dos dois grupos institucionalizados pode vir a se somar às inquietações já expressas?

Há dois aspectos que apontam caminhos para avançarmos nesse questionamento do valor heurístico daquelas matrizes: a desconfiança quanto à possibilidade de reificarmos as fronteiras entre esses "grupos" de jovens, e, portanto, de "tipificarmos" suas trajetórias; e a impressão geral de "mesmice", o pouco interesse suscitado pela análise das entrevistas dos jovens escolarizados, como se estas não trouxessem nada que já não soubéssemos por meio de vieses analíticos consagrados ao ponto do desgaste nos campos disciplinares das humanidades, e por vezes até mesmo diluídos em suas tantas apropriações pelo senso comum.

A impressão é de que esse grupo não coloca questões próprias, que não há nada a ser problematizado, compreendido ou endereçado por novas políticas de intervenção nas áreas da educação ou da segurança pública. Sua "função" nesse projeto não iria assim além de atuar como "pano de fundo" para fazer contraste com os dois outros grupos. Estes, em suas trajetórias "anômicas", seriam aqueles merecedores do interesse sociológico.

O relativismo básico que orienta as ciências sociais nos obriga, evidentemente, a duvidar disso. Nenhum grupo pode ser taxado de "desinteressante" por si mesmo, com a responsabilidade por resultados analíticos pouco instigantes the sendo imputada; o absurdo de tal "conclusão" dispensa maiores explicações. Como, então, reintegrar sua análise de forma enriquecedora ao projeto? Ou, colocando de forma mais provocativa: como fazer da "mesmice" um dado novo?

Eis a hipótese que gostaríamos de trazer para o debate: não seria o olhar sociológico sobre as trajetórias "anômicas" parte de uma "arqueologia do saber" que, ao construir "grupos" de jovens segundo o critério institucionalizado/ não institucionalizado, concorre para a cristalização daquelas formas matriciais de explicação dos comportamentos desviantes? Esse processo não estaria 
ainda mais profundamente entranhado na própria concepção da pesquisa ao considerar a escola como forma principal/desejável da institucionalização, opondo-se assim, por um lado, às formas "indesejadas" de institucionalização (as medidas socioeducativas) e, por outro, à não institucionalização? Não seria também a centralidade atribuída à experiência familiar e à relação família-escola no roteiro das entrevistas uma terceira versão desta "arqueologia" do saber?

Essa "arqueologia do saber" articularia assim escola, família e olhar sociológico, obrigando-nos a suspeitar dessa "interpretação" que nossos dados "sustentariam": a família como fundamental para manutenção do jovem na escola e a escolarização como fundamental para protegê-lo do tráfico e da violência. Afinal, se o resultado é esse, não estamos dizendo rigorosamente nada de novo, mas apenas repetindo velhas articulações já gastas até mesmo no senso comum...

Empreender esse exercício autorreflexivo exige de nós suspeitar de que o tributo pago às matrizes do pensamento conservador, sugerido na abertura deste texto, esteja infiltrado no próprio desenho metodológico de nossa pesquisa através da atribuição à escola do papel de critério central para a definição dos "grupos" de jovens. É um exercício incômodo, sem dúvida, mas essencial para que, ao colocar sob suspeição a percepção dessas trajetórias "escolarizadas" como trajetórias default, recuperemos a capacidade de olhar para esse grupo escolarizado de uma maneira que permita enxergar suas especificidades, furtando-nos assim à impressão moralmente conservadora e intelectualmente estéril de que "com este não precisamos nos preocupar".

\section{Referências}

BECKER, H. Outsiders: studies in the sociology of deviance. New York: Free Press, 1963.

BAUMAN, Z. Modernidade e Holocausto. Rio de Janeiro: Jorge Zahar, 1998.

CLARKE, R. (Org.). Situational crime prevention. New York: Criminal Justice Press, 1997.

DOWDNEY, L. Crianças do tráfico. Rio de Janeiro: 7 Letras, 2003. 
FONSECA, C. Da circulação de crianças à adoção internacional: questões de pertencimento e posse. Cadernos Pagu, Campinas, n. 26, p. 11-43, jan./jun. 2006.

KATZ, J. Seductions of crime. New York: Basic Books, 1988.

SILVA, H. R. S. Travesti: a invenção do feminino. Rio de Janeiro: RelumeDumará: Iser, 1993.

SILVA, H.; MILITO, C. Vozes do meio-fio. Rio de Janeiro: Relume-Dumará, 1995.

SOARES, L. E. Meu casaco de general: 500 dias no front da segurança pública do Rio de Janeiro. São Paulo: Companhia das Letras, 2000.

TILLEY, N. Crime prevention. Devon: Willian Publishing, 2009.

VELHO, G. Projeto, emoção e orientação em sociedades complexas. In: VELHO, G. Individualismo e cultura. Rio de Janeiro: Zahar Editores, 1981.p. 15-37.

WILSON, H. Parental supervision: a neglected aspect of delinquency. British Journal of Criminology, v. 20, n. 3, p. 203-235, 1980.

ZALUAR, A. O condomínio do Diabo. Rio de Janeiro: Revan: Ed. UFRJ, 1994.

ZIMRING, F. American youth violence. New York: Oxford University Press, 1998. 